(Житомирський національний агроекологічний університет) Lightning25960@gmail.com ORCID: 0000-0002-5468-0078

М. В. Мороз,

старший викладач

(Житомирський національний агроекологічний університет) moros.m.w@gmail.com

ORCID: 0000-0002-9557-9275

\title{
ПІДГОТОВКА СТУДЕНТІВ ЮРИДИЧНИХ СПЕЦІАЛЬНОСТЕЙ ДО УКЛАДАННЯ ТА ТЛУМАЧЕННЯ ІНШОМОВНИХ ДОГОВОРІВ
}

\begin{abstract}
У статті досліджено шляхи удосконалення курсу іноземної мови для студентів юридичних спеціальностей шляхом впровадження навчального матеріалу для формування та розвитку навичок укладання та тлумачення договорів іноземною мовою. Визначено типи навчального матеріалу, встановлено три етапи роботи з англомовними договорами: ознайомлення із типами та структурою договорів, укладання тексту договору на базі зразка та самостійне укладання тексту договору. Розроблено серію завдань та вправ з метою розвитку відповідних навичок.
\end{abstract}

Ключові слова: навички укладання та тлумачення договорів, англійська мова для студентів юридичних спеціальностей, ознайомлювальне, вивчаюче та переглядове читання.

Постановка проблеми у загальному вигляді. Відкриття іноземних підприємств в Україні, співпраця 3 закордонними партнерами, професійна мобільність $є$ чинниками, які обумовлюють важливість підвищення якості професійної іншомовної підготовки майбутніх юристів у ВНЗ.

Провідні освітні установи світу, серед яких юридичний факультет Університету Гельсінкі (Фінляндія), Стокгольмський університет (Швеція), Університет Карла (Чеська Республіка), провідні ВНЗ Польщі та Німеччини тощо, працюють над підвищенням рівня володіння студентами англійською мовою 3 метою забезпечення їх мобільності та конкурентоспроможності на ринку праці [1]. Розробляються англомовні курси, програми, багато уваги приділяється викладанню курсів англійською мовою в рамках магістерських програм.

Аналіз основних досліджень та публікацій. Іншомовна підготовка майбутніх юристів є предметом досліджень багатьох вітчизняних науковців, зокрема, Д. І. Демченко, Ю. Зелікмана, В. Шишкіної та ін. Проте опитування, проведене Д. І. Демченко, свідчить про те, що випускники не спроможні здійснювати ефективну повноцінну іншомовну комунікацію в професійній площині [2: 1]. Одним із пріоритетних напрямів реформування юридичної освіті у нашій державі Коломоєць Т. В. вважає посилення іншомовної підготовки студентів, зокрема, вивчення іноземної мови професійного спрямування, впровадження фахових мовних дискурсів та пілотних лекційних занять із фахових дисциплін [3: 16].

Окреслення невирішених питань, порушених у статті. Однією з істотних складових професійної діяльності юриста $\epsilon$ укладання договорів, що вимагає високого рівня володіння іноземною мовою та висуває такі вимоги до організації навчального процесу: реалізація міждисциплінарних зв'язків між курсом іноземної мови та фахових дисциплін, впровадження до змісту курсу іноземної мови мовленнєвих зразків, вживаних у міжнародних договорах, а також спеціальної юридичної термінології, необхідної для розуміння та реалізації істотних умов договору.

Метою статті $є$ дослідження засобів та шляхів навчання студентів юридичних спеціальностей укладання та тлумачення договорів іноземною мовою. Завдання, які необхідно вирішити: вибір текстового матеріалу для розробки навчального матеріалу; визначення вправ та завдань, спрямованих на опанування студентами теоретичного матеріалу, який стосується мовленнєвого аспекту укладання договорів та типової структури договорів; розробка завдань для розвитку вмінь читання та письма, пов'язаних із тлумаченням та укладанням договорів тощо.

Найбільш доцільним матеріалом для реалізації вищезазначених завдань є зразки англомовних договорів. Нижче ми наводимо онлайн-ресурси, які містять відповідні матеріали:

Веб-сайт English-Grammar.biz містить шаблони положень договору, типові договори англійською мовою, а також корисні статті та відео [4].

Веб-сайт FindLaw ${ }^{\circledR}$ for Legal Professionals містяться дійсні договори, укладені провідними міжнародними компаніями, зокрема, Alcatel, Amazon.com Inc., AT\&T Corp., Barnes \& Noble Inc., Boeing Co., Disney Walt Co., Hewlett-Packard Co., Hilfiger Tommy Corp. тощо [5].

Веб-сайт HLoom містить шаблони договорів, які стосуються найбільш популярних продуктів та послуг [6]. 
При опрацюванні англомовних договорів ми пропонуємо дотримуватися таких етапів:

Перший етап: ознайомлення із типами та структурою договорів.

Другий етап: укладання тексту договору на базі зразка.

Третій етап: самостійне укладання тексту договору.

На першому етапі (ознайомлення із типами та структурою договорів) доцільним є розвиток навичок ознайомлювального, вивчаючого та переглядового читання. При роботі з англомовними договорами всі ці види читання є необхідними залежно від контексту професійної ситуації.

Так, зокрема, навички ознайомлювального читання при опрацюванні англомовних договорів, застосовуються для таких цілей:

- визначити предмет та тип договору;

- встановити сторони договору;

- $\quad$ визначити наявність / відсутність суттєвих елементів структури договору;

- $\quad$ встановити наявність / відсутність типових положень договору тощо.

Наведемо приклади завдань для розвитку навичок ознайомлювального читання при роботі 3 англомовними договорами:

- $\quad$ Look through the agreement and name the parties thereto; the date of signing the agreement; the date when agreement becomes effective / expires.

- Студенти отримують різні договори (Service Agreement, Non-Disclosure Agreement, Export Agreement, License Agreement, Distribution Agreement, Web Site Development Agreement, Research and Development Agreement, Manufacturing Agreement, Consulting Agreement тощо). Завдання: Raise your hand if your agreement deals with: confidential information, provision of services, international sales of goods, producing new goods, providing consultations, developing new products, the right to exploit third parties' intellectual property, the right to sell products manufactured by another legal entity, launching a web site for your company.

- Завдання на опрацювання структури договору: Read the agreement and highlight the essential elements as follows: introductory provisions (red); definitions of key terms (yellow); purpose of the agreement (green); obligations of the parties (blue); assurances, warranties, representations or covenants (orange); signature block (purple); exhibits or attachments (grey). Compare your agreement with those of other students. Which elements are present in every agreement? Which of them remain unmarked?

Розвиток навичок вивчаючого читання, яке має на меті повне та глибоке розуміння змісту тексту, надання оцінки інформації, передання відомостей іншим та коментування окремих фактів [7: 202], вимагає розробки завдань на цілеспрямований аналіз змісту тексту за допомогою мовних явищ та логічних зв'язків. Перспективним з цією метою $є$ вивчення стандартних положень договорів, які $\epsilon$ типовими та загальновживаними (boilerplate provisions), зокрема, студенти мають опанувати терміни, визначення та скласти міні-словник сталих виразів для формулювання таких стандартних положень: оплата юридичних послуг (Costs and attorneys' fees), врегулювання спорів (Arbitration), регулююче законодавство (Choice of law), юрисдикція (Jurisdiction), відмова від висунення вимог (Waiver), самостійність положень (Severability), цілісність (Integration), доповнення та додатки (Attachments), повідомлення (Notice), відносини між сторонами (Relationships), відступлення прав (Assignment), обставини непереборної сили (Force majeure), заголовки (Headings), обмеження відповідальності у зв'язку із збитками (Limitations on damages), заяви та гарантії (Warranties), захист від відповідальності та відшкодування збитків (Indemnity), конфіденційність (Confidentiality), примірники (Counterparts).

Студентам пропонується виконати інтегроване завдання на опанування теоретичного та лексичного матеріалу:

а) доберіть визначення (мету) до назви стандартного положення.

Текстовий матеріал до завдання:

- Who pays the legal fees of another party in case of losing a legal dispute (Cost and Attorney's Fees);

- How the disputes are resolved, through arbitration proceedings or in a lawsuit (Arbitration);

- $\quad$ The legislation of what country will be applied to solve a dispute (Choice of Law);

- In what country will be lawsuits filed in case of a dispute (Jurisdiction);

- If a provision of an agreement is violated, this provision permits a party to give up the right to sue the other party, maintaining this right to sue if the breach happens in the future (Waiver);

- This provision allows to sever a specific provision of the agreement, while the rest of the agreement stays valid (Severability);

- This clause states that the provisions contain the final agreement between the parties, and the earlier agreements or memoranda of understanding lose their effect (Integration);

Attachments are included and constitute integral part of the agreement (Attachments);

- $\quad$ How the parties will communicate regarding the performance of the agreement (Notices);

- $\quad$ The parties agree on the relationship between them, as partners or employer/employee (Relationships); 
- $\quad$ The provision states whether the parties may transfer their rights or obligations under the agreement to a third party (Assignment);

- The provision suspends the agreement for the period of duration of unforeseen events (Force Majeure);

- The headings of the provisions do not hold any specific information or significance (Headings);

- $\quad$ The provision limits the amount of damages paid in the event of a dispute (Limitations on Damages);

- Representations and assurances of the parties regarding their obligations under the agreement (Warranties);

- $\quad$ The party agrees to pay damages to a third party that arise through its fault (Indemnity);

- $\quad$ The parties agree not to disclose specific information (Confidentiality);

- How many counterparts of the agreement the parties sign (Counterparts).

б) Прочитайте положення договору, визначте його назву:

- The Parties hereto are released from responsibility for non-fulfillment of their liabilities under the present Contract, in part or in whole, if such non-fulfillment is caused by circumstances beyond their reasonable control, namely: fire, flood, earthquake, riots, terrorism, military activity etc. Should the force majeure event arise, the time of fulfillment of the Contract obligations is extended for the period of duration of such events.

- The Seller hereby agrees to sell, and the Buyer hereby agrees to accept and make payment for the following equipment: supply as specified in Appendix No supplied in full conformity with the Specifications and in complete scope of

- All disputes and disagreements between the Parties hereto that may arise out of or in connection with the present Agreement shall be settled by way of negotiations between the Parties. Should the Parties fail to come to an agreement, the matter shall be submitted for settlement to arbitration with its seat in Stockholm, Sweden.

- This agreement supersedes all prior agreements between the Parties, written or oral, with regard to the subject matter hereof.

- Neither Party is entitled to transfer its rights and obligations hereunder to a third party without the other party's consent thereto in writing.

в) Проаналізуйте зразки договорів, наданих вам викладачем. Заповніть табличку (Fill in the table. First match the title with the definition of a boiler plate provision. Read the text of the agreement and write out the respective provision. Single out useful language for future reference) (Табл. 1. Стандартні положення договору).

Табл. 1.

Стандартні положення договорів

\begin{tabular}{|l|l|l|l|}
\hline Назва стандартного положення & $\begin{array}{l}\text { Мета / визначення } \\
\text { положення }\end{array}$ & $\begin{array}{l}\text { Текст положення (із } \\
\text { договору) }\end{array}$ & $\begin{array}{l}\text { Функціональні } \\
\text { зразки }\end{array}$ \\
\hline Costs and attorneys' fees & & & \\
\hline Arbitration & & & \\
\hline Choice of law & & & \\
\hline Jurisdiction & & & \\
\hline Інші положення (див. вище) & & & \\
\hline
\end{tabular}

Для розвитку навичок читання з метою пошуку необхідної інформації (вибіркове читання) студентам пропонуються такі типи завдань:

Навчальні завдання - відповідь на питання, тести множинного вибору, альтернативні тести тощо.

Завдання на юридичний аналіз тексту договору з метою наближення навчальної ситуації до реальних обставин професійної діяльності, наприклад:

- Юрист склав текст договору, користуючись шаблоном. Знайдіть невідповідності (наприклад, договір між компаніями з України, а місцем юрисдикції зазначена Швейцарія; сума відповідальності перед третіми сторонами перевищує вартість договору тощо);

- Поясніть, якими будуть наслідки, якщо випустити певне положення договору;

- Вирішіть, які положення договору врегульовують певні ситуації: наприклад, невчасне постачання партії товару; недотримання стороною положення про конфіденційність; залучення третіх осіб до виконання умов договору тощо;

На другому етапі навчання навичок укладання та тлумачення англомовних договорів студенти укладають договори на базі шаблонів. Корисним ресурсом для завантаження типових положень та зразків договорів англійською мовою $є$ веб-сайт English-Grammar.biz. Студентам пропонується заповнити пропуски в договорах мовленнєвими зразками, опанованими на попередньому етапі; вставити інформацію, якої бракує, з огляду на решту положень (пропущені назви сторін, обов'язки, заголовки, логічні блоки), з наданням відповідних підказок або без них. Також студентам пропонується укласти окремі положення із переліку стандартних на підставі вивчення тексту договору. 
На третьому етапі студентам надається ділова ситуація, для якої необхідно розробити договір самостійно. Так, наприклад, пропонується розробити договір на експорт продукції компанії, яка функціонує у місті (для Житомира, наприклад, такою компанією є 'Kromberg \& Schubert'). Визначаються сторони договору, предмет договору, а студенти в групах мають укласти текст договору, після чого в групах обговорити недоліки та переваги кожного варіанту.

Висновки та перспективи подальшого дослідження. У статті визначено алгоритм роботи над розвитком навичок студентів юридичних спеціальностей укладання та тлумачення договорів англійською мовою. Розроблено серію завдань на опанування теоретичного та мовленнєвого матеріалу та визначено ресурси для опрацювання під час вивчення курсу англійської мови професійного спрямування. Результати розвідки доцільно використовувати при розробці методичного посібника 3 укладання текстів англомовних договорів для курсу англійської мови для студентів юридичних спеціальностей.

\section{СПИСОК ВИКОРИСТАНИХ ДЖЕРЕЛ ТА ЛІТЕРАТУРИ}

1. Нітенко О. В. Деякі аспекти підготовки фахівців із права в університетах Європейського простору вищої освіти / О. В. Нітенко // Теорія і практика управління соціальними системами. - 2015. - № 1. - С. 98-104.

2. Демченко Д. І. Формування професійної іншомовної компетентності майбутніх юристів у фаховій підготовці : автореф. дис. на здобуття наук. ступеня канд. пед. наук : спец. 13.00.04 "Теорія і методика професійної освіти" / Демченко Діна Ісхаківна. - Харків, 2010. - 23 с.

3. Коломоєць Т. О. Реформування вищої юридичної освіти в України : пріоритетні напрями з урахуванням правового регулювання та запозичення позитивного європейського досвіду / Т. О. Коломоєць. // Вісник Запорізького національного університету. - 2014. - № 4. - С. 11-22.

4. Английский для юристов / Юридический английский [Електронний ресурс] // English-Grammar. - 2017. Режим доступу до ресурсу : grammar.biz/\%D0\%B0\%D0\%BD\%D0\%B3\%D0\%BB\%D0\%B8\%D0\%B9\%D1\%81\%D0\%BA\%D0\%B8\%0\%B9\% D0\%B4\%D0\%BB\%D1\%8F\%D1\%8E\%D1\%80\%D0\%B8\%D1\%81\%D1\%82\%D0\%BE\%D0\%B2.html.

5. Services Agreements [Електронний ресурс] // FindLaw for Legal Professionals. - 2018. - Режим доступу до pecypcy : http://corporate.findlaw.com/contracts/operations/services/.

6. Contract Templates [Електронний pecypc] // HLoom. - Режим доступу до ресурсу : http://www.hloom.com/more/sample-contract-templates/.

7. Методика викладання іноземних мов у середніх навчальних закладах : [підручник] / Кол. авторів під керівн. С. Ю. Ніколаєвої. - Вид. 2-е, випр. і перероб. - К. : Ленвіт, 2002. - 328 с.

\section{REFERENCES (TRANSLATED AND TRANSLITERATED)}

1. Nitenko O. V. Deiaki aspekty pidhotovky fakhivtsiv iz prava $v$ universytetakh Yevropeiskoho prostoru vyshchoi osvity [On the Issue of Training Legal Specialists in the Context of European Higher Education] / O. V. Nitenko // Teoriia i praktyka upravlinnia sotsial'nymy systemamy [The Theoretical and Practical Aspects of Social Systems Management]. - 2015. - № 1. - S. 98-104.

2. Demchenko D. I. Formuvannia profesiinoi inshomovnoi kompetentnosti maibutnikh yurystiv u fakhovii pidhotovtsi [Building the Professional Foreign Language Competence of Future Legal Professionals in the Course of Their Professional Training] : avtoref. dys. na zdobuttia nauk. stupenia kand. ped. nauk : spets. 13.00.04 "Teoriia i metodyka profesiinoi osvity" / Demchenko Dina Iskhakivna. - Kharkiv, 2010. - $23 \mathrm{~s}$.

3. Kolomoiets T. O. Reformuannia vyshchoi yurydychnoi osvity v Ukraini : priorytetni napriamy z urakhuvanniam pravovoho rehuliuvannia ta zapozychennia pozytyvnoho yevropeiskaho dosvidu [Reforming Legal Education in Ukraine in View of Regulatory Environment and the Best European Proctices] / T. O. Kolomoiets. // Visnyk Zaporizkoho Natsional'noho Universytetu [Newsletter of Zaporizhzhya National University]. - 2014. - № 4. S. 11-22.

4. Angliiskii dlia yuristov [English for Lawers] / Yuridicheskii angliiskii [Legal English] [Elektronnyi resurs] // English-Grammar. - 2017. - Rezhym dostupu do resursu : http://englishgrammar.biz/\%D0\%B0\%D0\%BD\%D0\%B3\%D0\%BB\%D0\%B8\%D0\%B9\%D1\%81\%D0\%BA\%D0\%B8\%D0\%B9 $\% \mathrm{D} 0 \% \mathrm{~B} 4 \% \mathrm{D} 0 \% \mathrm{BB} \% \mathrm{D} 1 \% 8 \mathrm{~F} \% \mathrm{D} 1 \% 8 \mathrm{E} \% \mathrm{D} 1 \% 80 \% \mathrm{D} 0 \% \mathrm{~B} 8 \% \mathrm{D} 1 \% 81 \% \mathrm{D} 1 \% 82 \% \mathrm{D} 0 \% \mathrm{BE} \% \mathrm{D} 0 \% \mathrm{~B} 2 . \mathrm{html}$.

5. Services Agreements [Elektronnyi resurs] // FindLaw for Legal Professionals. - 2018. - Rezhym dostupu do resursu : http://corporate.findlaw.com/contracts/operations/services/.

6. Contract Templates [Elektronnyi resurs] // HLoom - Rezhym dostupu do resursu : http://www.hloom.com/more/sample-contract-templates/.

7. Metodyka vykladannia inozemnykh mov u serednikh navchalnykh zakladakh [The Methodology of Teaching Foreign Languages in Secondary School] : [pidruchnyk] / kol. avtoriv pid ker. S. Yu. Nikolaievoi. - Vyd. 2-e, vypr. i pererob. - K. : Lenvit, 1999. - $320 \mathrm{~s}$.

\section{Ваценко С. В., Мороз М. В. Подготовка студентов юридических специальностей к составлению и толкованию англоязычных договоров.}

В статье исследованы пути усовершенствования курса английского языка для студентов юридических специальностей посредством внедрения учебного материала для формирования и развития навыков 
составления и толкования договоров на английском языке. Определены типь учебного материала, установлены три этапа работы с договорами на английском языке: ознакомление с типами и структурой договоров, составление текста договора на основании образца и самостоятельное составление текста договора. Разработана серия заданий и упражнений с целью развития соответствующих навыков.

Ключевые слова: навыки составления и толкования договоров, английский язык для студентов юридических специальностей, ознакомительное, изучающее и просмотровое чтение.

\section{Vashchenko S. V., Moroz M. V. Training Law Students to Draft and Interpret Agreements in English.}

One of the key issues of training legal professionals in Ukraine is lack of competence in applying English in their professional domain. While speaking remains a crucial part of language competence, more attention needs to be paid to reading and writing skills connected with drafting and interpreting agreements in view of the actual professional needs of future legal specialists. The article therefore is aimed at studying the specific skills to be developed that form the competence of drafting and interpreting agreements in English, followed by developing a working algorithm for building and developing the aforementioned skills. The material used for research mainly comprises a vast body of agreements concluded by reputable organizations and available in the public domain.

The following stages of developing skills of drafting and interpreting agreements were singled out based on the results of the study: a) introducing the types and the structure of agreements; b) drafting an agreement based on a template; c) unassisted drafting an agreement.

The set of tasks suggested to develop the aforementioned skills is based on the existing algorithms of teaching scanning, skimming reading and reading for detail. The tasks range from introducing the theoretical material to

those reflecting actual professional context of legal professionals. From studying general and boilerplate provisions of agreements, students proceed to analyzing the linguistic peculiarities of contracts and go on to interpreting existing agreements to analyze the significance of each paragraph. The algorithm leads the students to independent drafting of an agreement with a follow-up group analysis.

Key words: training legal professionals, drafting and interpreting agreements in English, scanning reading, skimming reading, reading for detail. 